\title{
FUNGSI HUKUM DALAM PERUBAHAN SOSIAL
}

Oleh: Rizki Yudha Bramantyo*

*Fakultas Hukum Universitas Kadiri

\section{A. Pendahuluan}

Manusia sebagai makhluk pemikir, dikaruniai kecerdasan senantiasa bersifat dinamis dan berusaha mencari cara yang lebih modern, lebih cepat dan mudah dalam memenuhi kebutuhan kehidupannya. Perkembangan kecerdasan dan daya pikir manusia memacu hingga ke batas kemajuan zaman, tekhnologi-tekhnologi canggih menjadi jawaban atas hasrat manusia yang selalu penasaran. Tekhnologi ini tentu saja mengakibatkan perubahan pada kehidupan manusia, baik itu perubahan pola hidup, perubahan perilaku, perubahan cara pandang serta pemahaman berfikir. Manusia dalam kehidupan sosialnya pun terus beradaptasi menyesuaikan dengan modernisasi. Dalam bidang ekonomi pun kegiatan ekonomi dapat menjangkau berbagai belahan dunia. Dikenalnya tekhnologi dalam dunia perbankan mengakibatkan dana dapat dipindah dengan mudah. Tentunya memberi dukungan kepada manusia untuk mengembangkan perdagangan daring. Berbagai bidang turut menyambut perubahan-perubahan sosial yang ada, perubahan sosial ini meliputi perubahan nilai-nilai sosial, kaidah-kaidah sosial, pola-pola perikelakuan, organisasi, susunan lembaga-lembaga kemasyarakatan, lapisan-lapisan dalam masyarakat, kekuasaan dan wewenang, interaksi sosial, dan lain sebagainya (Soekanto, 2014). Seperti yang di kemukakan oleh Suwarno dalam jurnalnya yang berjudul Perubahan Pola Pencaharian Nafkah Dalam kaitannya Dengan Persepsi Masyarakat Terhadap pendidikan, Suwarno menyatakan bahwa, "Masyarakat merupakan komponen penting yang menikmati dan menerima dampak pembangunan itu sendiri. Dalam perencanaan pembangunan hendaknya memperhatikan dan mengakomodasi masukan-masukan dari masyarakat. Pemahaman mengenai perubahan adalah prasyarat untuk memahami struktur. Orang yang memandang masyarakat sebagai sistem yang berada dalam keseimbangan dan yang mencoba menganalisis aspek struktural dari sistem atau masyarakat itu akan mengakui bahwa keseimbangan (equilibrium) hanya dapat dipertahankan melalui perubahan tertentu di dalam sistem tersebut. Perubahan ini terjadi sebagai tanggapan atas kekuatan eksternal yang menimpa sistem itu. Karena itu, baik perubahan internal maupun eksternal, diperlukan untuk mempertahankan keseimbangan 
dan tidak ada alas an logisnya mengapa pemahaman mengenai struktur diprioritaskan atas pemahaman mengenai perubahan. melekat di dalam sifat kehidupan sosial”

Namun demikian perubahan tidak hanya berdampak ke arah yang baik atau kemajuan, seringkali perubahan juga dapat berdampak kepada kemunduran. Perubahan sosial yang terjadi pada salah satu bagian kehidupan akan mempengaruhi bagian-bagian lainnya. Maka permasalahan kemasyarakatan akan semakin pelik, oleh karenanya dalam menelaah permasalahan perubahan sosial ini penulis membatasinya dengan hukum. Bagaimana pengaruh hokum terhadap perubahan sosial, bagaimana hukum mengatur masyarakat yang senantiasa berubah (dinamis) dan bagaimana pula perubahan hukum mempengaruhi perubahan-perubahan dibidang lainnya?

\section{B. Isi Substansi}

Menurut Suwarno (2013) dalam jurnalnya yang berjudul Masyarakat Sebagai Lingkungan Pembelajaran di Luar Kelas, Suwarno mengungkapkan bahwa "Perubahan sosial adalah sebuah keniscayaan yang terjadi seiring dengan makin teredukasinya masyarakat di suatu daerah untuk menjawab tantangan kehidupan. Makin kompleksnya permasalahan yang ada, masyarakat berfikir untuk menjadikan lingkungan tempat tinggalnya sebagai wahana pembelajaran". Perubahan-perubahan sosial adalah segala perubahan pada lembaga kemasyarakatan didalam suatu masyarakat, yang mempengaruhi sistem sosialnya, termasuk didalamnya nilai-nilai, sikap-sikap, dan pola-pola perikelakuan diantara kelompokkelompok dalam masyarakat. Para sarjana sosiologi juga mengadakan kasifikasi antara masyarakat-masyarakat yang statis, dimana perubahan-perubahan, secara relatif sedikit sekali terjadi dan berlangsung dengan lambat, sedangkan masyarakat dinamis merupakan masyarakat yang mengalami perubahan yang cepat.

Terdapat beberapa teori mengenai hukum dan perubahan-perubahan sosial,di antaranya: Menurut Max Weber, perkembangan hukum materiil dan hukum acara mengikuti tahap-tahap perkembangan tertentu, mulai dari bentuk sederhana yang didasarkan pada kharisma sampai pada tahap termaju dimana hukum disusun secara sistematis serta dijalankan oleh orang yang telah mendapatkan pendidikan dan latihan dibidang hukum, jadi perubahan yang terjadi pada sistem sosial dari masyarakat yang mendukung sistem hukum yang bersangkutan. 
Menurut Emile Durkheim yang pada pokoknya menyatakan, bahwa hukum merupakan refleksi dari solidaritas sosial dalam masyarakat, menurutnya didalam masyarakat terdapat dua macam solidaritas yaitu, bersifat mekanis yang terdapat pada masyarakat yang sederhana dan homogen,dimana ikatan dari warganya didasarkan pada hubungan-hubungan pribadi serta tujuan yang sama, serta yang bersifat organis. Menurut Sir Henry Maine bahwa perkembangan hukum adalah sesuai dengan perkembangan dari masyarakat yang sederhana dan homogen ke masyarakat yang telah kompleks sususnannya dan bersifat heterogen dimana hubungan anatara manusialebih ditekankan pada unsur pamrih.

Perubahan sosial yang terjadi didalam suatu masyarakat dapat terjadi oleh karena beberapa sebab. Sebab-sebab tersebut ada yang bersifat intern (yang berasala dari masyarakat), dan ekstern (luar masyarakat). Terdapat pula faktor-faktor yang mempermudah terjadinya perunaha apabila masyarakat yang satu melakukan kontak dengan masyarakat yang lain atau yang telah memiliki sistem pendidikan yang maju, ada pula faktor penghambat seperti sikap masyarakat yang terlaku mengagung-agungkan masa lampau (tradisionalme). Saluran yang dilalui oleh suatu proses perubahan sosial adalah lembaga kemasyarakatan. Mengenai factor eksternal, Suwarno (2017) dalam Jurnalnya yang bertajuk Budaya Huma Betang Masyarakat Dayak Kalimantan Tengah Dalam Globalisasi Telaah Konstruksi Sosial mengemukakan bahwa, "Eksternalisasi adalah suatu pencurahan kedirian manusia secara terus meneruske dalam dunia, baik dalam aktivitas fisis maupun mentalnya.Penyesuaian diri dengan dunia sosio-kultural sebagai produk manusia ("Society is a human product"). Produk aktivitas manusia-yang berupa produk-produk sosial terlahir dari eksternalisasi manusia. Eksternalisasi merupakan keharusan antropologis; keberadaan manusia tidak mungkin berlangsung dalam suatu lingkungan interioritas yang tertutup dan tanpagerak. Keharusan antropologis itu berakar dalam kelengkapan biologis manusia yang tidak stabil untuk berhadapan dengan lingkungannya.”

Dalam proses perubahan hukum pada umumnya dikenal adanya tiga badan yang dapat mengubah hukum, yaitu badan pembentuk hukum, badan penegak hukum, dam badan pelaksana hukum. Apabila hukum harus berubah agar sesuai dengan kebutuhan masyarakat, maka perubahan-perunahan tersebut tidak hanya tergantung pada suatu badan semata-mata. Perubahan sosial dan perubahan hukum tidak selalu berlangsung bersama-sama. Artinya pada keadaan-keadaan tertentu perkembangan hukum mungkin tertinggal oleh perkembangan unsur-unsusr lainnya dari masyarakat serta kebudayaannya atau mungkin hal 
yang sebaliknya yang terjadi. Apabila terjadi suatu hal yang demikian maka terjadilah suatu yang dinamakan social lag, yaitu suatu keadaan dimana terjadi ketidak seimbangan dalam perkembangan lembaga-lembaga kemasyarakatan yang mengakibatkan terjadinya kepincangan. Tertinggalnya kaidah hukum juga dapat menyebabkan terjadinya suatu disorganisasi dimanakaidah lama telah pudar, sedangkan kaidah baru belum di sususn, yang selanjutnya menyebabkan anomie yaitu suatu keadaan yang kacau.

Perubahan sosial yang baik semestinya diimbangi dengan pola pendidikan atau bentukbentuk pendidikan yang baik pula. Sehingga daripadanya pola piker masyarakat dapat terbentuk dengan baik dan menghasilkan generasi-generasi penerus yang mampu berfikir untuk masa depan. Implementasi pendidikan terhadap perubahan sosial ini pernah diteliti oleh Suwarno dalam jurnalnya yang lain yang berjudul Perubahan Pola Pencaharian Nafkah Dalam Kaitannya Dengan Persepsi Masyarakat Pedalaman Terhadap Pendidikan, Suwarno (2012) mengungkapkan bahwa "Salah satu faktor penting dalam ukuran keberhasilan pembangunan adalah ketersediaansumberdayamanusiayangsiap menjadi tenaga penggerak, dan pelopor pembangunan. Pembangunan yang berkesinambungan yang dilaksanakan pemerintah bertujuan meningkatkan taraf hidup, kecerdasan, dan kesejahteraan bagi seluruh rakyat secara merata. Demikian pula dengan kesempatan untuk memperoleh pendidikan dan pengajaran merupakan pencerminan dari kemerdekaan suatu bangsa. Kesempatan memperoleh pendidikan seiring dan sejalan dengan ketersediaan fasilitas berbagai pendidikan: perpustakaan, sarana laboratorium, sarana praktikum, sarana komputer, sarana laboratorium, berbagai buku penunjang, guru yang berkualitas, sistem penerimaan siswa baru yang benar-benar objektif, dan sistempendidikanyangbaik. Seiring dengan perihal tersebut di atas, maka di Tumbang Samba sampai dewasa ini sudah lebih dari cukup tersedia lembaga pendidikan formal, mulai dari Taman KanakKanak (TK) sampai dengan Sekolah Menengah Atas (SMA) dan pendidikan keagamaan mulai dari Ibtida'iyah sampai dengan Aliyah (setingkat SMA), dan secara rinci lembaga pendidikan formal tersebut berada di masing-masing desa yang antara lain dapat dijelaskan berikut ini, di desa Samba Danum terdapat 4 sekolah Taman Kanak-Kanak (TK), 4 Sekolah Dasar Negeri, satu Sekolah Dasar (SD) swasta, satu SMP Negeri, dua SMP swasta, satu SMA Negeri dan dua SMA swasta. Satu Taman KanakKanak (TK), satu Sekolah Dasar Negeri, dan satu SMP Negeri, serta satu SMA swasta yang berada di desa Samba Bakumpai. Dua TK dan dua SD Negeri serta satu SMPNegeri yang berada di desa Samba Katung, serta satu Taman Kanak-Kanak dan 3 
Sekolah Dasar Negeri yang berada di desa Samba Kahayan. Sarana prasarana pendidikan ditingkatkan terus demikian juga dengan tenaga pengajar, sehingga secara perlahan tapi pasti diharapkan terjadi peningkatan kualitas baik pendidikan maupun daya dukung sarana pendidikan. Peningkatan sarana pendidikan disesuaikan dengan anggaran yang tersedia di pemerintahan Kabupaten Katingan dan setia tahun ada peningkatan sarana fisik sekolah melalui pembangunan gedung baru seperti pembangunan kelas baru, perpustakaan sekolah, gedung pertemuan dan perbaikan gedung yang sudah ada. Pengadaan tenaga pengajar disesuaikan dengan kebutuhan di masing-masing sekolah yang disesuaikan dengan jumlah kelas yang ada dan anggaran yang tersedia.”

Terdapat beberapa fungsi hukum dalam mempengaruhi perubahan sosial di antaranya:

1. Hukum sebagai alat untuk mengubah masyarakat

Agent of change atau pelopor perubahan adalah seseorang atau sekelompok orang yang mendapatkan kepercayaan dari masyarakat sebagai pemimpin suatu atau lebih lembagalembaga kemasyarakatan. Suatu perubahan sosial dikehendaki atau direncanakan selalu berada di bawah pengendalian serta pengawasan pelopor perubahan tersebut. Hukum berfungsi secara tidak langsung dalam suatu perubahan sosial yang direncanakan, hasilnya tergantung pada pelopor perubahan, Apabila efektivitas penanaman (hasil posistif dari penggunaan tenaga manusia, alat-alat, organisasi, dan metode yang digunakan) besar dan kekuatan menentang dari masyarakatnya kecil, maka proses pelembagaan menjadi lancar.

2. Hukum sebagai sarana pengatur perikelakuan

Sebagai sarana social engineering hukum merupakan suatu sara yang ditujukan untuk mengubah perikelakuan warga masyarakat, sesuai dengan tujuan yang telah ditetapkan sebelumnya. Manusia memiliki struktur normatif didalam dirinya yang sekaligus merupakan potensi dalam dirinya untuk dapat mengubah perikelakuannya, melalui perubahan terencana didalam wujud penggunaan kaidah hukum sebagai sarana. Pokok didalam proses perubahan perikelakuan melalui kaidah hukum adalah konsepsi kaidah, peranan, sarana maupun cara untuk mengusahakan adanya konformitas. Pemengang peranan merupakan subjek hukum sedangkan peranan merupakan hak dan kewajiban baekaitan dengan kepentingan hukum. Berperannya pemegang peranan merupakan peristiwa hukum yang dapat sesuai atau berlawanan dengannya. Jadi kaidah hukum merupakan role expectation (dari pelopor) terhadap role occupant didalam proses social engineering. 


\section{Penutup}

Hukum adalah sanksi. Ungkapan tersebut telah banyak dikenal oleh masyarakat sebagai sebuah identitas, sebagai sebuah fungsi dari hukum itu sendiri. Hukum bersifat menata dan member batasan dari suatu tindakan manusia, agar tindakan tersebut tidak mencederai kepentingan orang lain. Perubahan sosial yang terjadi hendaknya menjadi pengarah kepada kehidupan dan tatanan sosial yang lebih baik, lebih rapi, saling menghargai sesama dan meraih ketentraman hidup bermasyarakat (Suwarno, 2012a, 2016). Perubahan sosial hendaklah diimbangi dengan perubahan hukum dan kesadaran masyarakat dalam berhukum. Agar momentum perubahan yang terjadi tersebut tidak mengarahkan sebagian masyarakat kearah penyimpangan sosial, munculnya tindakan-tindakan criminal yang merugikan dan lain sebagainya.

\section{Daftar Pustaka}

Soekanto, S. (2014). Pokok-pokok sosiologi hukum. Jakarta: Rajagrafindo Persada.

Suwarno. (2012a). Dampak larangan illegal logging dan illegal mining terhadap pendapatan masyarakat daerah pemekaran. JEJAK: Journal of Economics and Policy, 5(2). https://doi.org/10.15294/jejak.v7i1.3596

Suwarno. (2012b). Perubahan Pola Pencaharian Nafkah dalam Kaitannya dengan Persepsi Masyarakat Pedalaman terhadap Pendidikan. Jurnal Economia, 8(2), 164-180.

Suwarno. (2013). Masyarakat sebagai Lingkungan Pembelajaran di Luar Kelas. Jurnal Ilmu Sosial, Politik \& Pemerintahan, 2(2), 1-10.

Suwarno. (2016). Social Changes In Society Bakumpai Tumbang Samba , Katingan Central Kalimantan. Research on Humanities and Social Sciences, IV(4), 829-836.

Suwarno. (2017). Budaya Huma Betang Masyarakat Dayak Kalimantan Tengah dalam Globalisasi: Telaah Konstruksi Sosial. LINGUA, 14(1), 89-102. 